\title{
05 KONFLIK ANTARA NEGARA DAN MASYARAKAT SEKITAR HUTAN PASCA PELAKSANAAN KEBIJAKAN PENGELOLAAN HUTAN BERSAMA MASYARAKAT
}

Yanuardi

\begin{abstract}
Paper ini bertujuan untuk memahami perkembangan konflik antara negara dan masyarakat setelah kebijakan Program Pengelolaan Hutan Bersama Masyarakat (PHBM) yang implementasikan oleh Perum Perhutani. Datadata dalam studi ini bersumber dari Undang-Undang, Peraturan-Peraturan Pelaksanaan di bawahnya, hasil-hasil penelitian dan berita-berita di media. Dari hasil studi ini terungkap bahwa PHBM hadir dalam konteks untuk menyelesaikan konflik antara Perhutani dengan Masyarakat Desa Sekitar Hutan yang telah berlansung sejak masa kolonial,yaitu semenjak negara megembangkan pengetahuan Ilmiah dalam mengelola. Hutan. Konflik ini memuncak ketika Reformasi Politik berlangsung. Dalam proses Implementasi kebijakan pada awalnya PHBM menghadapi masalah ketidakpercayaan stakeholder terhadap Perhutani. Pada perkembangannya melalui proses sosialisasi yang melibatkan banyak pihak, kebijakan ini dapat diterima oleh Stakeholder. Saat ini kebijakan ini telah mampu membangun rasa saling percaya, mengurangi konflik, meningaktkan kemampuan masyarakat dalam bernegoisasi, megurangi pengeluaran biaya keamanan Perhutani, menurunkan tingkat pencurian kayu di Hutan Negara dan memulihkan legitimasi Perhutani sebagai lembaga yang mampu mengelola hutan di Pulau Jawa.
\end{abstract}

\section{Pendahuluan}

Governanceterma is a new words that emerge in the this decade. yang muncul dalam dedekade ini menggantikan kata Government dalam analisis politik dan kebijakan. The changes show that new political practice Perubahan ini menunjukan bahwa saat ini telah muncul praktek-praktek politik baru yang mengubah model pemerintahan yang sebelumnya berpusat pada pemerintah menjadi sebuah model yang menekankan keterlibatan Multistakeholder dalam proses kebijakan. Perubahan ini menunjukan bahwa dalam mengelola pemerintahan telah muncul kebutuhan ketrampilan baru, yakni mengelola jaringan masyarakat agar dapat mendeliberasikan kepentingan masing-masing agar dapat menghasilkan dan melaksanakan kebijakan sesuai dengan hasil proses deliberasi tersebut.

Bagi kalangan Ilmuwan politik dan pengamat kebijakan public, perubahan ini mebutuhkan kemampuan baru. Para peneliti membutuhkan kemampuan untuk mengamati isi dan proses deliberatif. Dalam mengamati hal tersebut penagamat dapat mengamati sejauh mana forumforum atupun jaringan-jaringan dialog kebijakan telah benar-benar 
mampu melahirkan dialog yang otentik, ataukah hanya sekedar menjadi proses untuk melegetimasi kebijakan yang dibuat oleh elite politik. .

Perubahan praktek politik dan pemerintahan ini juga terjadi di Indonesia.. Saat ini di level pusat maupun di daerah telah muncul banyak forum-forum yang melibatkan Multistakeholder. Forum-forum ini muncul diinisiasi oleh pemerintah, Lembaga Swadaya Masyarakat maupun Kelompok Masyarakat.

Tulisan ini akan menganalisis salah satu kebijakan yang berisikan kebijakan deliberatif secara substantif yang muncul dan telah berkembang di Indoensia, yaitu Kebijakan Pengelolaan Hutan Bersama Masyarakat (PHBM) yang diterapkan oleh Perhutani, lembaga yang mendapat wewenang mengelola hutan negara di Pulau Jawa. Kebijakan ini diarahakan untuk menyelesaikan konflik Perhutani dengan masyarakat serta pihak-pihak lain yang berkepentingan dengan pengelolaan hutan di Pulau Jawa. Sebelum melakukan analisis terlebih dahulu Penulis akan menguraikan tentang konsep Deliberative Public Policy dan latar belakang munculnya kebijakan PHBM di Pulau Jawa..

\section{Kebijakan Publik yang deliberatif}

Kebijakan Publik yang deliberatif (Deliberative Public Policy) adalah sebuah model kebijakan public yang muncul sebagai kritik terhadap kebijakan publik yang telah mapan sebelumnya. Kebijakan ini terinspirasi dari ide-ide teori kritis yang dikembangkan oleh Jurgen Habermas. Kebijakan ini mengkritik model-model kebijakan public yang teknokratis yang menekankan pada prosedur-prosedur positivistic yangdianggap oleh Habermas sebagai proses yang membuat manusia mengalami dehumanisasi. Konsep Habermas tentang Comunicative rationality telah membantupengembangan konsep deliberative Public Policy untuk mendorong munculnya sebuah kondisi kondusip bagi proses pengembangan pengetahuan yang emansipatoris dalam proses Kebijakan Publik.

Menurut John Dryzek model Deliberatif demokrasi muncul sebagai kritik terhadap model demokrasi prosedural. Bila dalam demokrasi prosedural kebijakan publik adalah hak dan kewenangan pengambil kebijakan yang telah terpilih melalui proses pemilu, kemudian dilanjutakan dilaksanakan oleh birokrasi, maka deliberatif demokrasi berpendapat bahwa proses demokratisasi dalam kebijakan Publik harus muncul dari proses deliberatif melaui proses dialog yang autentik. Meskipun demikian, kedua model ini tidak dapat ditempatkan pada posisi yang saling berhadapan, bahkan keduanya dapat diposisikan untuk saling melengkapi.

Dialog yang otentik sendiri adalah sebuah proses komunikasi yang memperbincangkan masing-masing kepentingan tanpa menggunakan cara-cara kekerasan. Proses ini mensyaratkan hilangnya dominasi melalui penggunaan kekuasaan, manipulasi, propaganda kecurangan, ancaman dan pemaksaan ideologi. Oleh karena itu, melalui proses ini aktor-aktor 
yang berdialog dapat berunding dalam posisi kesetaraan untuk dalam sebuah proses kebijakan publik.

Pelaksanaan kebijakan publik yang deliberatif dilakukan melalui sebuah proses manajemen yang tidak sentralistik, melainkan menekankan pada manajemen yang koloboratif. Dalam proses ini pihak -pihak yang berkepentingan dalam proses kebijakan hadir didorong beremansipasi dalam melakukan dialog yang otentik Keuntungan dari pelaksanaan model ini bukan hanya mampu memberikan jalan menyelesaikan konflik kebijakan yang muncul sebagai akibat manajemen kebijakan public tradisional yang sentralistik. Bahkan model kebijakan public telah mampu memberikan jaringan baru pada aktor-aktor yang berkepentingan, sekaligus mampu meningkatkan distribusi pengetahuan antara aktoraktor kebijakan yang terlibat.

\section{Konflik Negara versus Masyarakat Desa Hutan di Pulau Jawa a. Konflik Negara Versus Masyarakat dalam perebutan kontrol atas hutan jawa pada era kolonial.}

Klaim kontrol negara kolonial terhadap semua sumberdaya daya alam berawal pada masa Pemerintahan Gubernur Jendral Rafles yang menggunakan teori domein. Teori yang sangat berpengaruh dalam persoalan agrarian pada masa kolonial ini berpendapat bahwa semua tanah adalah milik raja atau pemerintah. Teori kemudian menjadi basis bagi Pemerintah Kolonial Belanda untuk mengeluarkan Undang-Undang Agraria pada masa itu yaitu Domein Verklaring tahun 1870.

Kontrol Negara tehadap sumberdaya hutan melalui pembentukan sebuah lembaga khusus sebenarnya berawal pada masa Gubernur Jendral Herman . W.Daenles yang telah membentuk sebuah lembaga pengelola hutan guna memulihkan hutan di Pulau Jawa yang telah hancur akibat penebangan terus menerus. Meskipun demikian kontrol tersebut belum efektif, karena belum ditunjang oleh pengetahuan Ilmiah dan belum dikelola kaum professional.

Kontrol terhadap Hutan baru berjalan efektif ketika negara kolonial mereproduksi pengetahuan ilmiah dengan mengundang Ahli kehutan dari jerman yang mebawa pengetahuan Ilmiah dalam mengelola (Scintific Forestry) . Pengetahuan ini beranggapan bahwa hutan harus dikelola secara ilmiah oleh orang yang menguasai pengetahuan mengelola hutan secara Ilmiah. Kehadiran Scientific forestry .Pengetahuan ini juga membuat negara mampu mengelola hutan secara efektif berdasarakan kaidahkaiadah ilmiah. Melaui pengetahuan ini Hutan dikelola dengan proses ilmiah seperti dengan jarak tanam dan penentuan perbatasan yang jelas. Kontrol efektif oleh negara ini telah menyingkirkan masyarakat desa sekitar hutan yang telah mengelola hutan selama berabad-abad melalui penerapan pengetahuan lokal yang telah dipelajari secara turun temurun.

Penyingkiran masyarakat desa hutan secara sistematis oleh negara ini tidak berarti membuat masyarakat diam. Selama berabad-abad 
masyarakat desa hutan tetap melakukan perlawaanan untuk mengatasi ketersingkiran meraka..Perlawanan yang umumnya dilakukan adalah dengan melakukan pencurian kayu di hutan negara yang sering merepotkan aparatur negara. Dengan demikian berdirinya Lembaga kehutanan yang dikelola dengan prinsip ilmiah pada masa belanda telah memunculkan konflik panjang antar masyarakat Desa -Hutan dengan aparatur negara pada masa kolonial.

\section{b. Pengeloaan hutan Pasca kolonial}

Pada masa kemerdekaan pola pengelolaan hutan yang diwariskan oleh Belanda tetap dipertahankan hingga pada masa reformasi politik. Meskipun demikian cara negara mengklaim semua sumberdaya alam tidak lagi atas nama teori domein, melainkan atas nama negara bangsa.

Pada masa kemerdekaan hutan di Pulau Jawa di Madura dimandatkan dikelola oleh Perum Perhutani. Pada masa sebeluym reformasi politik, Perhutani masih didominasi oleh wacana pegeloaan hutan yang diwariskan oleh pemerintah Belanda. Tata cara penegeloaan yang sentralistik dan berorientasi pada peningkatan produksi kayu semakin mendapat naunganya pada masa Orde Baru berkuasa. Orientasi pembangunan yang mengarah pada model pertumbuhan ekonomi telah menyebabkan Negara Orde Baru betul-betul mengarahkan pengelolaan Hutan Jawa untuk meningkatkan Pertumbuhan ekonomi. Segala macam bentuk gangguan masyarakat, dianggap kriminal,bahkan mendapat tuduhan musuh ideologi negara, dengan memberikan cap pada siapapun yang menganggu proses ini sebagai anti Pembanguan dan pengikut Partai Komunis Indonesia (PKI).

Meskipun pada masa Orde Baru pemerintah menekankan pada pendekatan keamanan, tidak semua proses pengamanan hutan pada masa ini dilakuakan dengan cara kekerasan. Mulai masuknya wacana pengelolaan hutan yang disebarkan oleh Food Agriculture Organisatition (FAO) yang menekankan perlunya perhatian pada kesejahteraan masyarakat dalam mengelola sumberdaya hutan, telah menyebabkan Perhutani juga melakukan pendekan kesejahteraan melalui programprogram Mantri-Lurah, dan Pembangunan Masyarakat desa Hutan (PMDH). Namun program-program ini tidak mencapai sasaran.

Pendekatan keamanan dan kesejahteraan yang tidak melibatakn masyarakat ternyata tidak mampu menyelesaikan konflik antara masyarakt desa dengan Perhutani. Pencurian kayu tetap terjadi, Perhutani harus membiayai biaya keamanan yang tinggi, kekerasan sering terjadi antara masyarakat dan aparatur Perhutani, dan kerusakan hutan tetap terjadi. Konflik antara masyarakat versus Perhutani mmuncak ketika reformasi politik terjadi, pada saat itu masyarakat secara kolektif melakukan perambahaan besar-besaran terhadap hutan negara yang dikelola oleh Perhutani. Aparatur negara yang tengah kehilangan legitimasi tidak berdaya dan tidak mampu menghadapi perlawanan 
masyarakat ini. Akibatnya mayoritas hutan yang dikelola oleh Perhutani rusak parah.

Dengan demikian pengelolaan hutan di Pulau Jawa pada masa kemerdekaan sampai pada masa awal Reformasi politik tidak mengalami perubahan. Pengelolaan yang terpusat pada Perum Perhutani dengan tidak memperhatikan aspek sosial telah menyebabkan Perhutani tidak mampu mengelola hutan dengan baik. Penyebabnya perhutani tidak mampu mengamankan hutan lantaran tidak mampu mengelola hubungan yang baik dengan masyarakat Desa_Hutan dan para pihak lain seperti pemerintah daerah yang berkepentingan dengan Pengelolaan Hutan Jawa..

\section{Reformasi politik sebagai jalan baru}

Konflik dalam pengelolaan hutan di Jawa telah berlangsung berabad-abad dari jaman kolonial hingga masa kemerdekaan. Konflik ini telah menyebabkan adminisratur kehutanan harus mengeluarkan biaya yang tinggi untuk menjaga kemananan hutan. Konflik ini juga telah menyebabkan Perhutani kesulitan menjaga kelestarian hutan. Permasalahan yang telah diwariskan secara turun temurun ini menyebabkan Perhutani kehilangan legitimasi sebagai penyelenggara kehutanan yang profesional

Krisis legitimasi yang dialami oleh Perhutani telah membuat para pengambil kebijakan di Perhutani melakukan perubahan kebijakan dalam melakukan kontrol terhadap hutan. Perhutani kemudian mengadopsi pengetahuan baru dalam mengelola hutan yaitu Social forestry yang disebarkan oleh FAO. Pengetahuan ini menekankan pentingnya integrasi aspek sosial,lingkungan dan ekonomi serta memperhatikan cara-cara yang deliberatif dalam mengelola hutan Program kebijakan yang dikeluarkan oleh Perhutani adalah Program Peneglolaan Hutan Bersama Masyarakat (PHBM). Dalam program ini Perhutani menekankan pentingnya bagi hasil terhadap hasil hutan. Programini didijalankan oleh Perhutani sejak 2001 berdasarkan pada keputusan Dewan Pegawas No 136/Kpts/DIR/2001. Tujuan dari Program ini adalah : (1) Meningkatkan rasa tanggung jawab dari Perhutani, dan pihak lain yang mempunyai kepentingan terhadap keberlanjutan sumberdaya hutan, (2) Memperluas peran Perhutani, masyarakat lokal dan aktor lain yang memiliki kepentingan dalam sistem pengelolaan hutan, (3) Membuat semua kegiatan pengelolaan hutan lebih adaptif untuk menjawab dinamika perubahan sosial di pedesaan; (4) Meningkatkan kualitas sumberdaya alam hutan ; (5) Untuk memberi stimulus terhadap meningkatnya pendapatan Perhutani, pendapatan masyarakat desa, pihak-pihak lain yang terkait

- Kebijakan PHBM menunjukan bahwa Perhutani tetap ingin mempertahankan klaimnya terhadap hutan di Jawa. Meskipun demikian, Perhutani telah berubah manajemen dalam pengelolaan hutan yang sebelumnya dipengaruhi oleh pengetahuan Scientific Forestry menjadi FAO forestry. Dalam cara-cara pengelolaan baru ini, Perhutani juga merubah 
model pengelolaan sebelumnya yang menekankan model Government yang berpusat pada pemerintah menjadi Governance yang mengangap penting pelibatan Multistakeholder. Dalam melaksakan model ini, Perhutani menerpakan model Manajemen pengelolaan hutan yang bersifat Koloboratif,yang dilakukan dengan membangun jaringan kerjasama dengan aktor-aktor yang berkepertingan dengan pengelolaan hutan di Pulau Jawa dan Madura, yaitu lembaga-lembaga seperti Lembaga Masyarakat Desa Hutan (LMDH), Lembaga Swadaya Masyarakat (LSM), Perguruan Tinggi dan juga Pemerintah Daerah. Isi kebijakan ini menujukan bahwa Perhutani telah memulai berusaha menerapkan kebijakan dengan menggunakan prinsip-prinsip deliberatif,yaitu melalui proses dialog terus menerus dengan Multistkaheholder

\section{Implementasi PHBM sebagai tawaran solusi konflik}

Perubahan kebijakan yang dilakukan oleh Perhutani melalui program PHBM memang berisi kebijkan yang menekankan prinsip deliberatif. Meskipun demikian, Kebijakan ini tidak langsung mendapat respon dan kepercayaan dari Multistakeholder yang akan dilibatkan. Ketidakpercayaan ini muncul karena anggapan yang apatis kepada Perhutani yang sebelumnya menggunakan kebijakan yang sentralistik. Selain itu, proses pengambilan kebijakan tersebut juga belum melalui proses yang deliberatif akibatnya kebijkan ini pada awalnya ditolak oleh para pihak yang ingin dilibatkan.Bahkan pihak-pihak yang ingin dilibatkan membuat membuat langkah-langkah yang berusaha menghilankan kalim Perhutani terhadap Hutan Negara. Contoh penolakan ini muncul di Kabupaten Wonosobo. Seiring dengan munculnya kebijakan Otonomi Daerah, DPRD di Kabupaten ini mengeluarkan Peraturan Daerah Pengelolalan Sumberdaya Hutan Bersama Masyarakat (PSDHBM). Perda ini mengklaim bahwa wilayah hutan di Kabupaten Wonosobo berada pada kontrol Daerah dan manajemen penyelenggaranya dilakukan melalui proses yang koloboratif. Pemerintah Daearah ini menolak PHBM dengan argumentasi bahwa hutan harus dikelola oleh daerah,sebab selama dikelola oleh Perhutani hutan mengalami krisis dan tidak memberikan kontribusi bagi kesejahteraan masyarakat di Daerah.Kemunculan Perda ini melahirkan konflik antara pemerintah pusat dan daerah. Pada Perkembangan berikutnya Perda ini dibatalkan oleh Pemerintah Pusat.

Dalam kondisi ketidakpercayaan tinggi dari para pihak yang berkepentingan denga hutan, Perhutani tetap berusaha membangun jaringan dengan para pihak pihak -pihak yang berkepentingan. Pada akhirnya konsep PHBM dapat diteima pihak pihak-pihak yang terlibat dalam konflik pengelolaan hutan di Kabupaten Wobnosobo, seperti pusat Kajian Hutan Rakyat (PKHR) Fakultas Kehutanan UGM yang sebelumnya menduikung Perda PSDHBi telah terlibat bekerjasama dalam mendukung dan memperkuat PHBM .demikian juga Pemerintah Kabupten Wonosobo saat ini telah mengembangka forum koloboratif dengan Perhutani guna menyelesaikan persolan lingkungan di Hidup pada kawasan hutan 
lindung didataran tinggi dieng melalui pembentukan Tim Kerja Peduli Dieng (TKPD).

Pada dataran Implemntasi kebijakan, Implemntasi PHBM telah memberikan hasil pada kedua bela pihak yang sebelumnya telah berkonflik panjang. Pada masyarakat desa sekitar hutan, berdasarkan penelitian kolaboratif yang dilakukan oleh CIRAD-CIFOR-Pusat Kajian Hutan Rakyat (PKHR) Fakultas Kehutanan UGM (untuk Indonesia), serta didukung oleh Perum Perhutani dan PT. MHP Muara Enim Sumatera menunjukan bahwa PHBM telah telah membawa perbaikan yang significan bagi kemajuan masyarakat terutama LMDH yang terlibat dalam PHBM. Mereka telah mampu meningkatkan kualitas organisasinya, mampu berdialog dengan Perhutani pada posisi kesetaraani,mampu meningkatkan kemampuan berwirausaha masyarakat desa-hutan, serta mampu meningkatkan kemampuan berorganisasi petani Desa-Hutan. .

Sedangkan bagi Perhutani sendiri, Penerapan kebijakan deliberatif melalui PHBM juga telah memberikan banyak manfaat, Pertama, Muncunya kepercayaan kepada Perhutani sebagai pengelola hutan dari sebagian besar Multistaeholder yang sebelumnya sudah kehilangan kepercayaan kepada kemampuan Perhutani untuk dapat mengelola hutan Jawa dengan baik. Hal ini dapat dibuktikan dari keprcayaan dari multistakeholder untuk bekerjasasam dengan Perhutani Kedua, Biaya keamanan tinggi akibat berkonflik dengan masyarakat telah menurun secara significan. Penyebabnya tentu saja karena masyarakat desa sekitar hutan tidak lagi dianggap menjadi ancaman, tetapi telah menjadi mitra Perhutani untuk bersama-sama mengelola hutan. . Ketiga, . Pencurian kayu yang sering terjadi pada wilayah hutan negara juga telah menurun secara siginifican. Hal ini dibuktikan dari data yang ditunjukan oleh mantan Direktur Utama Perhutani Transtoto handardari, bahwa selama dari pada tahun 2002 Pencurian hutan 1,539,334 pohon nwburun hingga 128.080 pohon pada tahun 2006

\section{Kesimpulan}

Dari uraian diatas telah terungkap bahwa kebijakan PHBM yang dikeluarkan oleh Perhutani adalah kebijkan yang secara subtansi menekankan proses deliberatif dalam mengelola hutan di Pulau Jawa. Kebijakan ini menekankan pada perubahan manajemen kebijakan yang sebelumnya tersentralistik, menjadi manajemen yang menekankan keterlibatan banyak pihak. Perubahan arah kebijakan ini dilakukan untuk memperbaiki manajamen pengelolaan hutan pada masa lalu yang telah menyingkirkan masyarakat desa sekitar hutan dan telah mengakibatkan munculnya konflik panjang antara lembaga penyelenggara kehutanaan dengan masyarakat desa-hutan di Pulau Jawa.

Pada awalnya, Penerapan kebijakan PHBM mendapatkan penolakan para pihak yang berkepentingan dengan proses penyelengaran kehutanan di Pulau Jawa. Penyebabnya model penyelenggaraan hutan yang sentralistik dan tidak mempedulikan kesejahteraan masyarakat desa 
sekitar hutan yang dipraktekan sebelumnya telah menyebabkan multipihak tidak mudah mempercayai Perhutani. Namun, seiring dengan berjalanya waktu dan upaya dialog yang terus menerus akhirnya proses ini mampu memunculkan rasa saling percaya antara masyarakat desa sekitar hutan dengan Perhutani, serta pihak-pihak lain yang berkepentingan dengan penyelenggaraan hutan di Pulau Jawa seperti kelompok bisnis dan pemerintah daerah.

Pada akhirnya penerapan kebijakan publik yang deliberatif melalui PHBM pada akhirnya melahirkan rasa saling percaya. Oleh karena itu, kebijakan ini telah melahirkan banyak manfaat bagi kedua bela pihak yang sebelumnya berkonflik panjang. Pada masyarakat Desa Hutan implementasi PHBM telah berhasil meningkatkan kualitas organisasi masyarakat desa hutan, meningkatkan kemampuan berdialog dengan Perhutani pada posisi kesetaraan,mampu meningkatkan kemampuan berwirausaha masyarakat desa-hutan, serta mampu meningkatkan kemampuan berorganisasi petani Desa-Hutan Sedangkan bagi Perhutani Pengimplementasian kebijakan ini telah membangun kembali legitimasi Perhutani untuk mengelola hutan, menurunkan biaya keamanan hutan dan telah mampu mengurangi pencurian kayu di Hutan secara significan.

\section{DAFTAR PUSTAKA}

Sejarah Kehutanan Indonesia I: Periode pra sejarah - tahun 1942, Departemen Kehutanan, 1986

— Sejarah Kehutanan Indonesia II: Periode tahun 1942 - 1983, Departemen Kehutanan, 1986

Awang, San Afri, 2006, Sosiologi Pengetahuan Deforestrasi: Konstruksi Sosial dan Perlawanan, Debut Press.

Dryzek, John S., 1987, Rational Ecology: Environmental and Political Economy, Basil Blackwell

Dryzek, John S., 1997, The Politic of The Earth: Environmental Discourses, Oxford University Press.

Dryzek, John S., 2000, Deliberative Democracy and Beyond: Liberals, Critics, Contestations, Oxford University Press.

Eckersley, Robyn, 1992, Environmentalism and Political Theory: Toward an Ecocentric Approach, University College London Press.

Eriyanto, 2001, Analisis Wacana: Pengantar Analisis Teks Media, LKIS, Yogyakarta,

Foucault, Michael, 2002, Kuasa/Pengetahuan, terjemahan, Bentang Budaya, Yogyakarta.

Foucault, Michael, 2007, Order of Thing: Arkeologi Ilmu-ilmu Kemanusiaan, Pustaka Pelajar.

Gardner, Robert, 1996, Environmental Politics, Contemporary Political Studies Series, Prentice Hall

Giddens, Anthony, 2000, Jalan Ketiga: Pembaruan Demokrasi Sosial, Gramedia Pustaka Utama. 
Giddens, Anthony, 2005, Konsekuensi-konsekuensi Modernitas, Kreasi Wacana.

Gorz, André, 1987, Ecology as Politics, Pluto Press.

Hall, D.G.E., 1988, Sejarah Asia Tenggara, Usana Offset.

Heck, Deborah Anne, 2003, Discovering Education Discourses of Citizenship education: In the environment related section of Australia's Discovering Democracy School Material's project, Dissertation, Australian Environmental Studies, Griffith University

Hefner, Robert W., 1999, Geger Tengger: Perubahan Sosial dan Perkelahian Politik, LKIS.

Held, David, 2004, Demokrasi dan Tatanan Global: Dari Negara Modern hingga Pemerintahan Kosmopolitan, Pustaka Pelajar.

Hoogvelt, Ankie, 2001, Globalization and the Postcolonial World: The New Political Economy of Development, Second Edition, Palgrave.

Humphreys, David, 1996, Forest Politics: The Evolution of International Cooperation, Earthscan Publications.

Jorgensen, Marrianne W., Phillips, Louise J., 2007, Analisis Wacana; Teori dan Metode, Pustaka Pelajar

Keck, Margaret E. and Sikkink, Kathryn, 1998, Activist beyond Borders: Advocacy Networks in International Politics, Cornell University Press.

Keraf, A. Sonny, 2002, Etika Lingkungan, Penerbit Buku Kompas.

Latif, Yudi dan Ibrahim, Idi Subandi (Ed), 1996, Bahasa dan kekuasan Politik wacana di Balik Panggung Orde Baru, Mizan.

Li, Tania Murray, 2002, Proses Tranformasi Daerah Pedalaman di Indonesia, Yayasan Obor Indonesia, Jakarta.

Liftin, Karen T, 1994 Ozone Discourses; Science and Politics in Globar Environmental Cooperation, Columbia University Press.

Mallarangeng, Rizal, 2002, Mendobrak Sentralisme Ekonomi: Indonesia 1986-1992, KPG

Moleong, Lexy J., 2005, Metodologi Penelitian Kualitatif, Rosda.

Muhaimin, Yahya A., 1990, Bisnis dan Politik: Kebijakan Ekonomi Indonesia 1950-1980, LP3ES.

Peet, Richard, Theories of Development, The Guilford Press

Peluso, Nancy Lee, 1992, Rich Forest Poor People Recourses Control and Resistance In Java, University of California Press.

Peluso, Nancy Lee, Watt, Michael, 2001, Violent Environment, Cornell University Pres

Pieterse, Jan Nederveen, Development Theory: Deconstructions/Reconstructions, Vistaar Publications

Purwo Santoso, The Politics of Enviromental Policy-making In Indonesia: A studi of State capacity, 1967-1994, Departement Of Government London School Economics and Political science University Of London 1999.

Resosudarmo, I. A. Pradnja dan Colfer, Carol J. Pierce (Ed), 2003, Ke Mana Harus Melangkah?: Masyarakat, Hutan dan Perumusan Kebijakan di Indonesia, Yayasan Obor Indonesia. 
Rich, Bruce, 1999 (Terj), Menggadaikan Bumi: Bank Dunia, Penghancuran Lingkungan dan Krisis Pembangunan, INFID

Ritzer, George, 2003, Teori Sosial Postmodern, Kreasi Wacana.

Santoso, Hery, 2004, Perlawanan di Simpang Jalan: Kontes Harian di Desadesa Sekitar Hutan di Jawa, Damar.

Shimogaki, Kazuo, 1993, Kiri Islam: Antara Modernisme dan Postmodernisme; Telaah Kritis atas Pemikiran Hassan Hanafi, LKIS.

Simon, Hasanu, 1999, Pengelolaan Hutan Bersama Masyarakat (Cooperative Forest Management): Teori dan Aplikasi pada Hutan Jati di Jawa, BIGRAF, Yogyakarta.

Simon, Hasanu, 2004, Aspek Sosio-Teknis Pengelolaan Hutan Jati di Jawa, Pustaka Pelajar, Yogyakarta.

Sugiono, Muhadi, 2006, Kritik Antonio Gramsci terhadap Pembangunan Dunia Ketiga, Pustaka Pelajar, Yogyakarta,

Tim Lapera (Ed), 2001, Prinsip-prinsip Reforma Agraria: Jalan Penghidupan dan Kemakmuran Rakyat, Lapera Pustaka Utama.

Wiratno, dkk, 2004, Berkaca di Cermin Retak: Refleksi Konservasi dan Implikasi bagi Pengelolaan Taman Nasional, The Gibbon Foundation Indonesia. 